\title{
THE DISCOURSE OF SEX AND MARRIAGE IN THE NOVEL THE CURSE OF BEAUTY BY INDAH HANACO
}

\author{
Fiqih Aisyatul Farokhah, Sri Kusumo Habsari, dan Mugijatna \\ Universitas Sebelas Maret, \\ echa.elfaro@student.uns.ac.id
}

\section{ABSTRAK}

Seks merupakan unsur penting dalam perubahan peradaban.Bahkan, kehidupan manusia seolah tidak dapat terhindarkan dari seks dan seksualitas.Meskipunbegitu, definisi keduanya baik seks dan seksualitas sendiri memilik itafsiran yang berbeda di tiap-tiap budaya. Hal inidapat dilihat melalui bagaimana Negara memiliki campur tangan terhadap persoalan tubuh, khusunya seksualitas. Begitu pula dengan para perempuan yang bekerja sebagai SPG yang tidak pernah lepas dari seks dan seksualitas. Kehidupan seksualitas mereka selalu menjadi sorotan bagi public terlebih lagi mereka tidak seperti perempuanperempuan lainya yang mendambakan kehidupan dalam sebuah institusi perkawinan sebagai tujuan hidup mereka dalam mengekang seksualitas mereka.Artikel ini berusaha untuk menunjukkan makna diskursus seksualitas dan perkawinan dalam novel The Curse of Beauty karya Indah Hanaco analisisrepresentasiseksualitas SPG dalam novel "The Curse of Beauty". Desain penelitian ini adalah deskriptif kualitatif. Data diambil dari semua deskriptif mengenai penampilan tubuh SPG untuk memahami makna naratif dari tubuh berdasarkan teoriwacana Foucault.

Kata kunci: Seks, Pernikahan, Diskursus, Sales

Promotion Girl (SPG). 


\section{ABSTRACT}

Sex is one of important factors human life, But human life cannot be avoided by sex and sexuality. Even so, high-quality sex and sexuality itself have different interpretations in every hour of culture. This can be seen through how the State has intervened in matters of the body, especially sexuality. Likewise with women who work as SPG who have never been separated from sex and sexuality. Their sex lives are always in the spotlight for the public, moreover, they are not like other women who crave life in a marriage institution as their life's purpose in curbing their sexuality. This article attempts to analyze the representation of the sexuality of SPG in the novel "The Curse of Beauty". The design of the research is descriptive qualitative. Data are taken from all descriptive concerning SPG body appearance to understand the narrative meaning of the body. It applies Foucault's discourse theory.

Keywords: Sex, Marriage, Discourse, Sales Promotion Girl (SPG)

\section{A. Introduction}

Sexual conversation cannot be broken by sex and strength. Sex is defined by Foucault as sexual relations, sexy behavior, desires and how someone ventures sexy desire (Kali, 2013: 52). Sex since the beginning of the day is now no better in civilization. Not only that, human life seems inevitable from sex and sexuality. Even so, the definition of both sex and sexuality itself has different interpretations in each culture. Some say that sex is taboo and not worthy of discussion in the general public, some who view sex as a fundamental part of humans. This can be seen through how the State has intervened in matters of the body, especially sexuality. 
Foucault also shows that sexuality is no longer an impulse that arises from within (biological) but rather in the form of behavior and thoughts which are subordinated by power relations, which are then carried out for other purposes outside the interests of sexuality itself.In his analysis, Foucault also emphasized that it is not biological sex that produces discourse, but instead discourse produces sexual. In this case, it is the discourse of knowledge-power that creates a reality about sexuality. So it can be said that sexuality is the result of the construction of knowledge (social).Therefore, sexuality is a historical formation and cultural construction that is constructed to regulate sex. That is, each culture has its own concept of sexuality.

The cultural construction of the Indonesian people views sex and sexuality as issues that are discussed carefully. This is due to the influence of social processes, customs, culture, and religion. This is evidenced by the existence of a rule to impose a female body covering arising from the construction of the Minangkabau community.According to local customs, women are considered more polite if they cover their bodies by wearing a head covering. The application of socio-cultural construction increasingly reaps a lot of support through the application of the hijab rules in schools. Meanwhile conceptually, school is a meeting space between social classes, gender, construction of sexuality and reproduction(Bourdieu and Passeron 1977; Branson and Miller 1984; Connell 1987; Willis 1977).Thus, the body is the main site and a source of identity and construction of subjectivity. The application of these strict rules is intended so that women's bodies do not become sexual objects and become public consumption (Parker, 2009).

Although it can be said that the body is a source of identity and construction of subjectivity, the definition of the body also implies a reflection of social conditions. So 
that the body becomes the meeting point of the interface with other organs, but the body is also a very private part of the human component. Appearance and body style signify awareness and involvement with the social environment. In other words, the absence or containment of body movements or expressions can also indicate an active politeness agency (Parker, 2009). Unlike Minangkabau, sexuality in Nusa Tenggara is constructed by the culture of the local community as a symbol of fertility in heterosexual marriage as the most correct context for the expression of sexuality (Bennett, 2007).

Meanwhile, Javanese women's sexuality is constructed by the community through their domestic role. Javanese women have been educated that their sexuality is for men. All women's sexual potential is directed at them. Although essentially male and female sexuality is built on the same foundation.Men's satisfaction is constructed on how much they feel satisfied. Here are some dogma contained in Javanese texts which indirectly can be said that the duty of a woman is none other than to serve her husband (SudewainSusanto (ed), 1992: 38-44). With this dogma, women no longer have authority over their own bodies because everything related to women becomes the full right of husbands. Kate Millet believes that a personal thing is not really personal. Furthermore, sexuality is a political one. Sexual politics concerns the atmosphere of socialization for men and women in categorizing temperament, roles and status (Prabasmoro, 2006: 292).

In this modern century, there is a shift in the concept of traditional sexuality. Women's sexuality is no longer something that should be taken care of only for their husbands but is something that can be a tool for making money. Here, the sex industry provides opportunities for them to earn money instantly through the practice of 
sexual exploitation of women by being traded to become commercial sex workers (PSK). Therefore, according to Weeks, the community should need to control the erotic life of their people so as not to cause major problems in the process of social interaction. This is because what is defined as "sexuality" in essence and its implications differ in each individual as well even though the desires of sexuality come from the same individual but in different historical periods (Suryakusuma, 2012: 161). The sex industry is growing rapidly especially in metropolitan areas and influences the construct of sexuality in its society.

Women's sexuality in the modern age is used as a field to reap profits. Female nudity is used as satisfaction, desire, erotic fantasy, and sexual exploitation. This can be seen with the number of night entertainment industries built along the streets of metropolitan cities. The number of discos, nightclubs, massage parlors, karaoke and pubs or bars that nest in metropolitan cities is a promising business field. The mentality of the community with regard to sexuality contributed to the sexuality discourse of the night entertainment industry and its workers. This is because sexuality is always a pretense of truth that is covered for certain interests (Kali, 2013: 70). A well-known news report kompasiana.com shows data from the DKI Jakarta Regional Government as of 2011 stating that as many as 670,000 people became night entertainment workers and most of them were women who were widowed, students and even students (www.kompasiana.com).

Various types of sexuality construction that develop in the social community are used by the owners of capital to make as much profit as possible. The number of capital owners along with political strategy acts as an actor of cultural transformation. The paradox behind the taboo of sexuality is the culture medium used to get a lot of financial 
benefits. Sexuality is increasingly being displayed to the public.Passion for sexuality can boost the popularity of the products they create. From the process of producing this sexual desire, women are always objects. Their bodies are considered capable of increasing product sales. And this happens because their bodies are built by a cultural construction that makes women a tool to attract desire.

Women's obedience to all orders, especially those from patriarchal ideology has brought women false thinking that they can contribute to themselves by entering the realm of women's subordination through their participation in industrial and cultural practices. Finally, they put themselves in a state of lack of authority. According to Bordo, women can experience the illusion of power when they are created to be faithful. He showed the effect of obedience that they felt personally liberated and changed culturally but actually they were still in the same bondage (Brooks, 1997: 288).

Disciplinary efforts experienced by women are evident with body approach to make-up, as well as the selection of clothing complete with accessories that lead to a body that is shaped, controlled, and dominated to be exploited and presented with a perfect form to male consumers according to the shadow they. The body here becomes a locus for the continuation of the power contest. Foucault, Bartky, and Lee argue that "woman's body is an ornamented surface too, and there is much discipline involved in this production as well" (Benedicta, 2012: 5).

This discipline of the body which refers to exploitation is in line with what Foucault said that sexuality always has a connection with power. From this power system, sexuality discourse was formed. Before this system operates, sex stands alone and lives on a subject. When the 
power relationship moves through a discourse strategy, the discourse about sex that is incorporated into the power matrix becomes sexuality. This process is referred to by Foucault as the way in which sex is put into discourse" (Kali, 2013: 60).

This condition is experienced by those who work as Sales Promotion Girl (SPG). They are required to look beautiful and perfect according to male perceptions and mass media image. This kind of thing can be seen from the exploitation of their bodies by the owners of capital to get big profits through the formation and dissemination of their body parts so that the image of the products they sell will also be exposed. As a product icon, to support their performance, of course, they also need to consume various beauty products. They become product objects for capital owners through advertisements for beauty products. Sumrahadi argues that the problem of seduction always duplicates new ways to get mutualism symbiosis (Baudrillard, 2006: xxvi). Therefore, according to their function as the backbone of the marketing division in each company, they have been tested to find out the sensual potential of their own bodies. Not only that, they also have to dress sexy as a form of communicating their body and themselves as a method of consolation work.

This means that the problems of sex and sexuality always influence the conscious and unconscious nature of the Indonesian people. This condition inspires a world of literacy. This reality is represented through popular novel works. This is because the pop novel always goes through a process of socialization, starting from the private space of the author entering the publiccum forum, then circulating to the public with various interests. The description of the pop novel becomes intact and complete when the disclosure 
of its collective aspects is successfully conveyed so that it can be said that pop novels are social works. The meaning of pop novels should be more understandable social work more clearly if the problem is placed in a paradox, as well as the tension between individuals and society (Mohamad, 1988:56).

Thus both pop and magazine novels always give a colorful picture of the living conditions of women by raising the contrast between the lives of men and women.Not a few of these works that describe the position of men are always safer than the depictions of women's lives which are full of demands. Not only that, but men are also often portrayed as social actors with a very broad scope. Even so, both pop novels and magazines or advertisements have the same purpose, namely; to expose readers to social problems (Handajani 2011). Nurfaidah (2017) entitled Dampak Disfungsi KeluargaTerhadap Mitos Kecantikan Dalam Novel The Curse Of Beauty: Metro life style Sales Promotion Girl has analyzed the change of the character in the novel to the beauty concept because there is a family dysfunction.

The research is focused on analyzing the representation of the sexuality of SPG in the novel "The Curse of Beauty". The design of the research is descriptive qualitative. Data are taken from all descriptive concerning SPG body appearance to understand the narrative meaning of the sexual body. It applies the sexual discourse theory of Michael Foucault. Foucault shows that sexuality is no longer an impulse that arises from within (biological) but rather in the form of behavior and thoughts which are subordinated by power relations, which are then carried out for other purposes outside the interests of sexuality itself. In his analysis, Foucault also emphasized that it is not biological sex that produces discourse, but instead 
discourse produces sexuality. In this case, it is the discourse of knowledge-power that creates a reality about sexuality. So that it can be said that sexuality is the result of the construction of knowledge (social) (Mills, 2003: 35).

\section{B. Discussions}

\section{Women through literary work}

The novel is one type of literary work. The novel can be said as an author's media to offer ideology to its readers. Through literary works in this case in the form of novels, authors can influence the views of life or the ideology of their readers. This can be seen from the conflict between figures that show in the structure of literary works, the author shows the existence of an attempt to fight for the ideology that he adheres to. Nevertheless, among male writers and female writers have different perspectives or ideologies in the style of their writing form.Morris (1993) says that every writer has a unique style, there is never the same.

If male writers are usually more likely to portray women through their sometimes deviant feelings and perspectives and are more in favor of their own people. While women writers more often appoint women as their central theme.Not only that, women writers more often display the position of women who are inferior to men. Not a few of their works also tell of an oppression from the existence of patriarchal culture. This is because in old discourses, women's sexual function is close to giving birth to children or reproducing and then life is perpetuated to raise children. So that women tend not to have rights to themselves (Melani, 2003: 104).

Among the many femaleauthors who make patriarchal cultural oppression against women, one of them is Indah 
Hanaco. Through his work the curse of beauty, he tried to bring up the discourse of sexuality as a form of resistance to the discourse of sexuality that developed in society through the form of body politics and sexual violence experienced by figures who worked as sales promotion girls (SPG).

SPG itself today has become a special attraction in the industrial world. SPG here is a means of direct persuasion that offers incentives or more value to the power of selling products, distributors, or consumers directly so that the process of buying and selling is immediately created. With this important function, it is not surprising that many of the producers/companies that recruit women with certain requirements. For women, they must be beautiful, friendly, and easy to use interesting words to capture consumers.Domestic changes to the public sector will open opportunities to get income that allows meeting the needs of life. Unfortunately, that fact is not in line with expectations. The public sector capitalizes on female workers as a cheap marketing tool to achieve infestation to attract economic growth in factories (Sudayat, 2014: 47).

By using SPG, actually, they have got two advantages at once. First, from promotional products, people will get all the information and are burdened with sales targets that must be achieved every day. Another benefit is that sometimes SPG products will also consume products to support their appearance. Usually, experience with SPG cosmetic products. They hope that using beautiful and attractive women will increase sales of their products and brands will be more popular than other brands on the market.

The importance of the role of SPG is not commensurate with the negative image attached to them. Not only negative images, but they often encounter difficulties when they are in the field. Starting from those who are underestimated 
and often isolated in the environment. Until the forced use of uncommon clothing (tight, transparent, and sexy) until the accessory invites leads to sexual harassment. Nonetheless, these bad things in no way discouraged them from pursuing the world of SPG. Instead, he proved his profession was not a problem with his personality. One of the bad images is a prostitute. He is always listed as a poor woman because he has a side job as a prostitute. In fact, not all SPGs are like this.

\section{Sex and Marriage Discourse in Novel The Curse of Beauty}

Sex is considered a taboo thing first. At this time, sex is no longer considered sacred and sacred. Sex for some people is a lifestyle that must also be respected.And of course, everyone is free to express it. As with the practice of living together or premarital sex is a practice that is opposed by the community because it is considered to violate the values of eastern courtesy and religious teachings.However, in today's metropolitan life, living together is not taboo and reprehensible. Rejection of this practice is also not always based on religious morality, but something more rational and pragmatic.

In general, in Indonesia, people still cannot accept couples living together premarital. Cynical satire from neighbors will often make the ears hot.On the other hand, living together has the risk of unclear status so that when a dispute occurs it will be very difficult to process law and there is a need for a written agreement between the two parties.

Discourse about living together cannot be separated from the view of premarital sex. At present, there is a shift in views regarding premarital sex. 
“Mereka bercerita tanpa sungkan seakan aku tidak ada di sana.Seakan aku tidak akan kaget mendengarnya. Mulai dari masalah uang, hingga tempat tidur meski tidak dibahas secara spesifik.Aku merasa jengah, namun sepertinya mereka tidak keberatans amasekali" (The Curse of Beauty, 2012:128).

“They told stories without hesitation as if I wasn't there. As if I won't be surprised to hear it. Starting from the problem of money to bed, although not specifically discussed. I feel embarrassed, but it seems they don't mind at all "(The Curse of Beauty, 2012: 128).

From the scene above, according to the author's perspective show women who work as SPG also have a side a job as mistress are proud of their status. They are not shy to tell their deviant behavior in front of the public even there is a stranger. No secret more about their sexual life whereas it should be privacy. This condition can be seen from the following expression "They told stories without hesitation as if I wasn't there. As if I won't be surprised to hear it. Starting from the problem of money to bed, although not specifically discussed" From the topic that becomes taboo from some people is not the same as they think. Such bedroom activities are usually considered as the private problem is no longer for themselves but it has been being the public consumption. This condition is shown in the following dialog "Starting from the problem of money, to bed, although not specifically discussed. I feel embarrassed, but it seems they don't mind at all". They are voluntarily become the mistress even they know this position never give the advantages. They truly know this position always bring them to lose even though they have material as the reciprocal.

The conditions reflected in the events above show that women who feel proud of telling their achievements in 
conquering men in return for more true material show how they have drowned their narcissistic nature.Narcissistic women are women who adore the body and all the curves of their sexual organs as a reflection of their assumption built in by patriarchal culture. Women values lie in their femininity where they are required to look pleasant, charming, and attractive to the opposite sex (Pranoto, 2010: 113).

As like the women condition in this following passage shows the difficult position of being second women or mistress

"Ketika seorang laki-laki berselingkuh entah sudah menikah atau baru memiliki kekasih - siapakah yang mendapat hujatan dan tudingan paling keras? Pasti perempuan yang jadi selingkuhanya".

"Laki-laki selalu dianggap 'normal' saja jika berselingkuh. Perempuan selalu disudutkan karena berani menjadi penggoda bagi kaum laki-laki yang sudah memilikipasanganini" (the curse of beauty, 2012, 107).

"When a man cheats on whether he is married or has a new lover - who gets the loudest blasphemy and accusations? It must be the woman who is cheating on her".

"Men are always considered" normal "only when having an affair. Women are always cornered because they dare to be tempting for men who already have this partner "(the curse of beauty, 2012, 107).

Through the above dialog, the author has shown the second place position of women who are being the second woman or mistress in men life is not a good choice. In this sentence "When a man cheats on whether he is married or has a new lover - who gets the loudest blasphemy and accusations? It must be the woman who is cheating on 
her" can be seen their low position in a relationship. They always become the side that is always blasphemed and blamed continuously. On the contrary, men are always in the lucky position. They are never blasphemed and blamed. Moreover, they are always in the right position. As like in this sentence "Men are always considered" normal "only when having an affair. Women are always cornered because they dare to be tempting for men who already have this partner ". This condition shows women have marginalized through their sexual position in married or unmarried life.

Although married or unmarried is optional for every human. It does not mean women who are married is more appreciated more. In fact, marriage has become the double load for them. How come they become a wife of the man that means they should take care of themselves, their husband and their children or their husband family and also their house in 24 hours every day without extra payment. Moreover, they still have to satisfy their husband in the bed. Then, if they choose to do not choose married they are also bullied by social environment because they choose the easy relationship without obligation to take care of the house, but only herself and her men.In infidelity is basically a form of abuse of marriage, of oneself and of women. In this campaign, what was emphasized was the role of the wife as a sex provider. The wife is responsible for keeping the husband from cheating on satisfying the husband's sexual desires. In other words, if the husband is having an affair, it is due to the role of the wife who cannot satisfy her husband (Munti, 2005: 88). Thus it can be said that this condition is nothing but domestication of women.

The assumption experienced by women here is predicted as an interest with political nuances that cannot be separated from a patriarchal culture that is still inherent in society, especially among men. These interests are 
manifested in efforts to return women to only dwell on domestic matters (female domestication).Domestication of women is closely related to the myth about women identified with 3M: masak (cooking), manak (giving birth) and macak (self-dressing) (Munti, 2005: 99). This myth again puts women in a subordinate position under men. This myth is what feminists try to eliminate.

Domestication can also be in the form of negative accusations that have not been fully correct. This has indirectly made them in positions that have been disadvantaged because of the labeling of negative images attached to them. Generally, women who come from stereotypes attached to them. For example, marking that starts from the assumption that women are preening is in order to provoke the attention of the opposite sex (Fakih, 2013: 16).

\section{Marriage Discourse and Women}

The marriage system is an important institution in society as the beginning of the formation of a family. Family institutions will give legal rights to each husband and wife to have sexual relations, procreation, and parenting, organize work in the household according to the division of labor according to sex, and transfer of property and other forms of inheritance. Family institutions will eventually regulate social bonds between individuals based on affinity (ie, marriage) and conspiracy (ie, blood or genetic linkages). Marriage is an important institution for the formation of the smallest community unit, the family. Through a happy marriage, a happy family will be born. The importance of the family is not only as a place of the relationship between husband and wife or children with parents, but also as a series of relationships between social networks of family members, and a larger network of people. In such a position, 
a person has not been considered complete in his life if he has not been married (Farida dkk, 2007: 11).

Even so, not all agree with the idea that marriage is a happy end to a relationship that two lovebirds live. Some of them consider a relationship without the existence of marriage ties to be more pleasant because there are no obligations that must always be obeyed by both parties with the existence of legalization forces through the law.As long as both agree with all the commitments agreed by both if only to enjoy sex it will be felt easier with no marriage ties. Because maybe some people believe that marriage is only an institution to control someone or just a media to show their power and donate to others. Foucault also argues power is everywhere. The intervention of power into sexuality occurs through body discipline and body science, and through the politics of the population that regulates birth. Power begins to administer the body and regulate people's private lives. Correspondingly, resistance to power is everywhere.

Thus, many of the women who work as especially those who prefer to have an affair with aresavings, prostitute, and concubine as their side work are not only working as SPG.This may be because some of them think that this is easier for them because of the absence of ties by husbands who may not approve if they have a career while it cannot be denied that not all men are able to meet all the needs of their wives and their families with abundance of assets and to get a better and better job with high wages is not possible because some of the women are blocked by an education diploma. So that inevitably just become SPG that they can and of course to have this profession will be very contrary to the will of the social environment, especially the husband. Because even though they are allowed to become SPGs, definitely, they will only become SPGs with 
the lower class because they are hit by their marital status. And this will add more shame and only become a burden for her husband and family. Because it is appropriate that a woman who is married only has the obligation to remain at home to be a housewife and caregiver for her children. And our subordinate position is in the household, family, and relationship with a man (Ruedadkk, 2007: 144).

With a variety of risks like this, making many women, especially those who work as SPGs, prefer a dark world with work that can never make sense as well as having a side job which is certainly not worthy of work. However, according to their field of view, it is precisely the work that some people think is not good but according to them is a good and easy thing. They do not have to with all the demands and the burden of taking care of the house and children which will make them bored and bored. They also do not need to just be submissive and obedient to their men in return for a living that honestly will not be able to meet the endless needs and of course the interests of their children must be the most important. This is clearly different from their status without the existence of a marriage bond that they still remain free to do everything they want and the feeling of anxiety about their family's needs, especially their children and they still can have fun spending the hard-earned money. they themselves and when the money runs out they just need to find other customers who are richer so they get sexual pleasure and material at once.If you grow up with hopes for equality and career, then you will soon be traumatized when you get yourself trapped at home taking care of the baby (Rueda dkk, 2007: 145).

Not to mention when they have to deal with the process of childbirth which of course will damage their body shape and decrease their vitality. The things they have taken care of and have cared for years in an instant 
will be damaged.Coupled with all the fatigue that they can because they have to be awake cyan and night giving ASI or caring for and providing for all the needs of their babies.Being a mother in a social situation is now a sign and stamp, a tool and method for women. Being a mother is a chain that is imposed on the blood and flesh of women; it will disrupt the sense of love and instinct(Rueda dkk, 2007: 147).

“siapa bilang aku nggak ngerti? Aku ngerti banget.Kamu lupa apa yang terjadi sama aku dan Martin? Tapi kasus kita beda. Aku ketemu Martin setelah dia nikah.Tapi kamu?Kamu malah terima kesepakatangilaitu!"(The Curse of Beauty, 2012: 300).

"Who said I don't understand? I really understand. You forgot what happened to me and Martin? But our case is different. I met Martin after he married. But you? You actually accept the crazy agreement! "(The Curse of Beauty, 2012: 300).

Through the above dialog, the author has shownthat the world of SPG can be said to be vulnerable to the world of prostitution, women calling and saving men. Although this does not happen to the whole SPG, it does not rule out the possibility of them being doubled as women. In fact, perhaps among them are indeed intentional and ambitious to plunge into this black valley because they think the amount of reward they will receive with what they do. And even for some of them, their side jobs are more promising if compared to the weight they have to go around to just introduce and sell products. Coupled with the achievement targets that they must achieve to get additional bonuses. Of course, the job of just straddling and just living feeling high in sex is more tempting. 
Absolutely they are well aware of every risk they take. Some of them are also well aware of the dangers of the double life they are living. About how bad views will always overshadow them. About how social conditions isolate and stay away from them so that they too will be isolated from social life. Not only that, the psychological burden will be experienced by them. However, there may also be some of those who are unaware of their distorted choice until they feel that regret has struck them. And this is a result of the teachings of women will always rely on the body to be ideal and revered with a standardization process with the intention of equalizing identity and self-esteem. Women are taught standards that are currently worshiped as ideal and are also taught to equate self-identity and appreciation with appearance (Melliana, 2006: 101).

"Irvin, kekasihku, tersenyum pada orang-orang
yang yang menyalaminya dan mengucapkan
untaian doa dan selamat.Isteri cantiknya pun sama.
Mereka tampak sangatserasi, saling melengkapi"
(The Curse of Beauty, 2012: 301).

"Irvin, my lover, smiles at the people who greet him and say a prayer and congratulations. His beautiful wife is the same. They look very harmonious, complement each other "(The Curse of Beauty, 2012: $301)$.

Based on the excerpts of the data quoted above, it can be seen from the glasses of the writer how the women who work as SPGs told in the novel prefer a relationship that is far from a marriage institution that is perceived as complicated and difficult for them. However, in fact, they themselves put themselves in a complicated and difficult position because they chose an illicit relationship and only 
became a man's wife who had married. They may get all sexual and material satisfaction without the need to care for children, however, they are actually not in a position that always benefits themselves continuously. There was a time when they never felt prioritized and only became distractions wrapped in words of love, however, when the man was told to choose they could only be silent and obviously they would not want and were unable to die his legal wife for their mistress.

In addition, the position of mistresses is weak in the eyes of the law, and they are in an unfavorable position if something happens to them or the struggle for the property is clear that they do not have any of the limits of their choice. In addition, with the negative accusations that are always attached to them, of course, they are always regarded as dirty and despicable women because they become male deposits even though their material status is more than sufficient. Another reason that might make them prefer this dark path is that they are afraid of losing authority to their own bodies. Because when they are married, the authority is no longer theirs, but their husbands are fully owned. Power is related to supervision and control, which does not have to be carried out in a repressive form (prohibition or punishment), but instead is creative and productive, which is often carried out by the use of stimulation (the formation of desire) (Munti, 2005: 15).

“Seminggu setelah pesta pernikahan nan megah itu, Irvin muncul di hadapanku.Senyumnya mengalahkan cerahnya mentari sore.Aku bias merasakan kebahagiaan mengepul dari setiap pori-poriku.Lidahku ingin bertanya tentang bulan madunya.Tentang malam pengantinya. Tentang perasaan saat di pelaminan.Tapi Aku mengingat kesepakatan kami. Irvin mengharamkan semua pertanyaan tentang sesuatu yang jawabanya akan menggarami 
lukaku. Kami bahkan tidak pernah membahas tentang kedatanganku kepestanya waktu itu" (The Curse of Beauty, 2012: 301).

"A week after the magnificent wedding party, Irvin appeared before me. His smile beat the sunny afternoon sun. I can feel happiness billowing from my pores. My tongue wants to ask about the honeymoon. About the night replacement.About feeling while at the wedding. But I remember our agreement. Irvin forbade all questions about something that the answer would scratch my wound. We didn't even discuss my arrival at the party at that time" (The Curse of Beauty, 2012: 301).

Based on the excerpts of the above data according to the author's perspective, it can be seen that to navigate a life that cannot be said to be a good life with the position of women who work as SPG with their dark side as a woman saving a man who has married not as a right decision. However, this difficult decision is not a wrong decision as well, where women here assume that whatever their profession, regardless of what people think of all forms of criticism, and the insults they have to accept, they are still human too. And every human being has the right as an individual to choose how the way of life must be lived also how the love story will be lived. Even so, a choice that is too risky for them does not necessarily take the decision itself. As is well known that hereditary teachings which say that women are weak creatures who prioritize their sense of reason dwell in a strong reason so that many men exploit these women's weaknesses in their interests.This condition is not realized by some women, or on the contrary, maybe they are actually aware of the guile of these men and they continue to affirm their offer simply by the word love or material rewards and the more attention they get from them. A woman is only a Rahim and an ovary, she is no 
more than a female who is considered a second-class being by men because it only functions as a baby factory (Pranoto, 2010: 29). Therefore, there are very many men who see women only in terms of their sexual potential to fulfill their lust alone.

As in the following phrase "A week after the magnificent wedding party, Irvin appeared before me. His smile beat the sunny afternoon sun. I can feel happiness billowing from every pore of mine "it can be seen that only with a smile emanating from it is able to blind the eyes, hearts, and minds of women so that they gladly accept a decision that is very bad for themselves. That is a true foolishness like all accusations and assumptions directed at women as believed so far or is a form of women's struggle against the tradition of marriage as the ultimate goal of a sacred relationship between men and women and virginity myths that have been rooted in the community that a relationship without marriage also has a sacred bond that is able to build its own happiness even though there are other parties who are hurt but return to its nature that every individual also has the right to achieve their happiness. The husband of the upper class in power has his wife as he has his female slaves not only because of his power over his wife's dead life but through his control of his wife's fertility. Seclusion and isolation of women, virginity cults and capital punishment for women who commit adultery (and never men) are all proof of total male control over life, freedom of movement, sexuality and female death (Rueda dkk, 2007: 84).

\footnotetext{
"Aku manusia biasa, mustahil tidak tergelitik oleh godaan. Aku punya cinta yang sangat besar, tidak mungkin mengabaikan orang yang kucintai. Aku menyadari cinta dibangun oleh kasih-sayang, gairah, dan hasrat"(The Curse of Beauty, 2012: 305).
} 
“I'm an ordinary person, it's impossible not to be tempted by temptation. I have a huge love, it is impossible to ignore the person I love. I realize love is built by love, passion, and desire "(The Curse of Beauty, 2012: 305).

Based on the citation data above, it can be seen how the author shows his point of view towards women who work as SPG that are so heavily tendered that according to some people it is inappropriate to establish a relationship with the opposite sex with a love even though not with marriage ties. Whereas the difference between men and women is actually derived from the process by which before they were created it was made to be male or female through the hopes of those around them to be born as male or female. So if they are then born as women who are far from their hopes of giving birth to a boy and when they become adults they prefer to be a person who is SPG and violates their nature as women who should stay at home by seeing their family's fate the destroyed like Leala or like Kimi who was forced to work as an SPG and the savings of a rich man who had married to help support his family's economy. Or with a background of professions that some people think is very low so they don't have the opportunity to enjoy the beauty of love that can make their lives more beautiful even with a very sad grief with a variety of negative images, insults, insults, and exploits that always overshadow their life. Women are not born, they are made. The creation of a man or woman is a kind of non-stop process that begins before birth; starting from when people imagine whether babies conceived are male or female. Even walking rituals are no more a journey than someone who does not have sex (English: it) to be male (he) or female (she) (Saptiawan, 2007: 12).

“Namun, aku sama sekali tidak pernah menduga-meski dalam mimpi teraneh pun-bahwa Kimi memilih jalan ini. 
Berprofesi ganda, menjadiSPG sekaligus gadis panggilan". Ya Tuhan....

"Aku terkenang perbincangan dengan Keenan di Sabtu lalu.Kalau dia menyinggung tentang yang dipromosiin tidak hanya sebatas produk yang diwakili. "Aduh. (The Curse of Beauty, 2012: 349).

"However, I never even wondered in the oddest dreams - that Kimi chose this path. Double profession, become an SPG and call girl. Oh, my God....

"I remember the conversation with Keenan last Saturday. If he mentions what is promoted, it is not only limited to the product being represented. "Ouch. (The Curse of Beauty, 2012: 349).

The citation of the data above shows the author's point of view that it is true that some of these SPG have side jobs as call women, savings women, and even commercial sex workers. And do not rule out the possibility of work as SPG is only a mask for them to peddle their bodies and get extraordinary customers both physically and materially. Conscious or not, only they know. He has become an SPG whose double profession is done solely by economic pressure or because of the opportunities and opportunities for them to do so because of a large number of their customers who come from the upper class so that they have enough money to support and provide material pleasure to several women at once.Every decision that is taken will present a risk and a separate impact on themselves. The image of a woman who remains in an environment that is damaging to her and how she gradually overlaps in some way to such portrayal so that she unwittingly enters into her own view (Hoigard\&Finstad, 2008: 20). 


\section{Conclusion}

Women's sexuality is formed from gender construction where women and men are always distinguished by their sex. This difference then affects how one must behave as a feminine woman and a masculine man. This difference also then raises their different roles in the community order system in which a man is in the public sector and is more suitable and placed in jobs that smell physical, mental, brain and skills.Conversely, more women in the domestic sector seem to be private so they should only be silent at home with busy taking care of the household or just caring for their husbands and children. However, this condition is inversely proportional to the novel by Indah Hanaco entitled the Curse of Beauty. Women are told to be independent and try to break the rules of patriarchy by leaving their domestic territory but they live into the public domain as many SPG through obstacles by only being seen from their body's sexuality so that both themselves and others use the beauty of their bodies as a tool to gain material benefits.Nonetheless, they have shown their efforts to fight sexuality discourses that are developing in a society where women's sexuality is only seen as a second sex and only has the function of giving birth and obeying her husbands in marriage. However, they prefer to live their lives as SPG as well as women calling, savings women even to commercial sex workers who are far from a marriage and domestic duty to serve their husbands, children, and families. They have the freedom to determine their own way of life. 


\section{BIBLIOGRAPHY}

Barker, Chris. (1999). Cultural Studies. London: SAGE publication.

Baudrillard, Jean. (2006). Ekstasi Comunikasi. Yogyakarta: Kreasi Wacana.

Bordo, Susan. "Feminism, Foucault, and the Politics of the Body". In Ramazonaglu, Caroline (ed). (1993). Up Against Foucault: Explorations of Some Tensions Between Foucault and Feminism. Routledge. pp. 179202.

Emka, Moammar. (2005). Jakarta Undercover. Sex $n^{\prime}$ the City. Jakarta: Gagas Media.

Hall, S. (1997). Representation: Cultural Representations and Signifying Practices. London, Thousan Oaks, \& New Delhi: SAGE Publications.

Hanaco, Indah.(2012). The Curse of Beauty. Malang: Rumah Kreasi.

Handjayani,Suzie. (2012). Young and Restless: Representing Male Adolescents with the Spirit of Reform in Hai Magazine. The Asia Pacific Journal of Anthropology, Vol. 13, No. 523 October 2012: 469-483.

Hidayat, S. Rahayu. (1997). Sejarah Seksualitas: Seks dan Kekuasaan Michael Foucault. Jakarta: Gramedia Pustaka Utama.

Hoigard, Cecile \&Finstad, Liv.(2008).Tubuhku Bukan Milikku, Prostitusi, Uank dan Cinta. Yogyakarta: Pustaka Pelajar. 
Hollows, Joanne. (2000). Feminisme, Feminitas dan Budaya Popular. Yogyakarta: Jalasutra.

Kress, Gunther dan Van Leeuwen, Theo. (2006).Reading Images.London: SAGE Publication

Kali, Ampy.(2013). Diskursus Seksualitas Michael Foucault. Yogyakarta: Solusi Offset.

Parker, Lyn. (2008). To cover the Aurat: Veiling, sexual morality and agency among the Muslim Minangkabau, Indonesia. Intersections: gender and sexuality in Asia and the Pacific. The Asia Pacific Journal of Anthropology, Vol. 16, 13 March 2008: 1-76.

Mills, Sara. (1997). Discourse. London and New York: Routledge.

Munti, BataraRatna. (2005). Demokrasi Keintiman Seksualitas di Era Global. Yogyakarta: LKIS

Parera, Jos Daniel. (1988). Sintaksis. Jakarta: PT Gramedia Pustaka Utama.

Piliang, Yasraf Amir. (2003). Hipersemiotika, Tafsir Cultural Studies atas Matinya Makna. Yogyakarta: Jalasutra.

Pranoto, Naming. (2010). Her Story: Sejarah Perjalanan Payudara. Yogyakarta: Kanisius.

Prabasmoro, AquariniPriyatno. (2006). Kajian Budaya, FeminisTubuh, Sastra, dan Budaya Pop. Yogyakarta: Jalasutra.

Rueda, Marisa, Rodriguez, Marta \& Watkins, Alice Susan. (2007). Feminisme untuk Pemula. Yogyakarta: Resist Book. 
Roger, F. Mary. (2009). Barbie Culture, Ikon Budaya Konsumerisme. Yogyakarta: Relief.

S. Melliana Annastasia. 2006. Menjelajahi Tubuh Perempuan dan Mitos Kecantikan. Yogyakarta: LKIS

Saptiawan, Hadi Itsna Sugihastuti. (2007). Gender dan Inferioritas Perempuan. Yogyakarta: Pustaka Pelajar.

Suryakusuma, Julia. (2012). Agama, SeksEKekuasaan. Depok: Komunitas Bambu.

Wieringa, Saskia. (2002). Sexual Politics in Indonesia. New York: PALGRAVE MACMILLAN.

Wolf, Naomi. (2002). The Beauty Myth: How Images of Beauty are Used Against Women. New York: Harper Collins Publishers. 